\title{
The effectiveness of training resiliency skills on soldier's mental heath
}

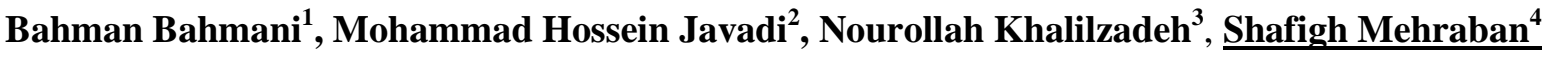 \\ 1-Associative Professor in counseling, Department of Counseling, University of Social Welfare and \\ Rehabilitation Sciences, Tehran, Iran. ORCID: 0000-0001-5485-3314 \\ 2- Assistant Professor in social worker, University of social welfare and rehabilitation sciences, Tehran, Iran. \\ ORCID: 0000-0001-9747-2730 \\ 3- Assistant Professor in Psychology, Payame Noor University, Urumia, Iran. ORCID: 0000-0003-4479-153X \\ 4-PHD student in counseling, Department of Counseling, University of social welfare and rehabilitation \\ sciences, Tehran, Iran. ORCID: 0000-0003-2912-769XＥ-mail: sf.mehraban@gmail.com
}

Received: 29/04/2018

Accepted: 11/11/2018

\section{Abstract}

Introduction: Entering to the mandatory service period affects one's mental health. One of the ways to improve mental health is to learn resilient skills.

Aim: This research intends to study the effectiveness of training resiliency skills on soldier's mental health.

Method: The statistical society included conscripts in Kermanshah police headquarter, among whom 30 people were selected using the method of availability and were accidentally appointed in the groups of control and test.to gather data, we used the Goldberg general health questionnaire with $28 \mathrm{~m}$ questions. The data we gathered was analyzed using spss 17 . Covariance test analysis results showed that training resiliency skills had a significant effect on improving soldier's mental health $(\mathrm{p}<0.01)$.

Results: according to the results, it can be said the program of training resiliency skills improves the soldier's mental health.

Conclusion: therefore, this training program, workshops and creating consulting and supportive groups can be one of the interventional programs in order to improve the soldiers health.

Keywords: Resiliency skills, mental health, soldiers

How to cite this article : Bahmani B, Javadi M H, Khalilzadeh N, Mehraban Sh. The effectiveness of training resiliency skills on soldier's mental heath.. Shenakht Journal of Psychology and Psychiatry. 2018; 5 (4): 78-86 .URL :http://shenakht.muk.ac.ir/article-1-291-fa.pdf

Copyright ( 2018 the Author (s). Published by Kurdistan University of Medical Sciences. This is an open access article distributed under the terms of the Creative Commons Attribution-Non Commercial License 4.0 (CCBY-NC), where it is permissible to download, share, remix, transform, and buildup the work provided it is properly cited. The work cannot be used commercially without permission from the journal. 


\title{
اثربخشى آموزش مهارتهاى تابآورى بر سلامت روان سربازان
}

\author{
بهمن بهمنى '، محمد حسين جوادى'، نوراله خليل زادهّ، شفيق مهربان \\ ا. دانشيار، كروه مشاوره، دانشكاه علوم بهزيستى و توانبخشى تهران، ايران.

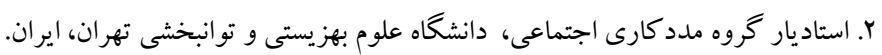

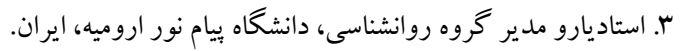

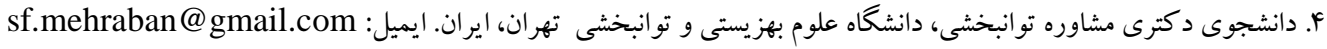

مقدمه: ورود به سربازى سلامت روانى فرد را تحت تأثير قرار مىدهد. يكى از راهكارهاى بهبود سلامت روان افراد ياد گيرى مهارت هاى تاب آورى است.

$$
\text { هدف: هدف يزوهش حاضر بررسى اثربخشى آموزش مهارت هاى تابآورى بر سلامت روان سربازان بود. }
$$

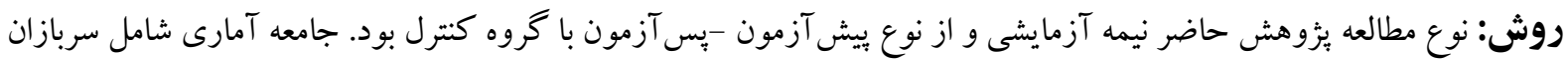

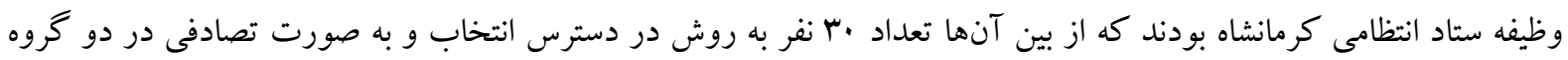

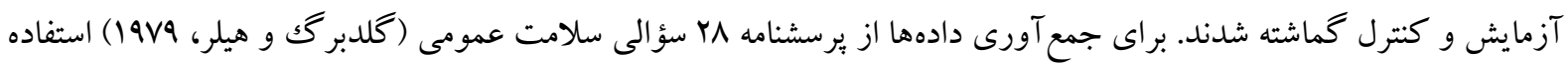

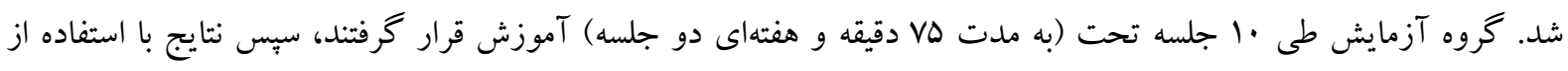
تحليل كواريانس تحليل شدند. يافتهها: نتايج آزمون تحليل كواريانس نشان داد كه مداخله آموزش مهارت هاى تاب آورى در افزايش سلامت روان سربازان در

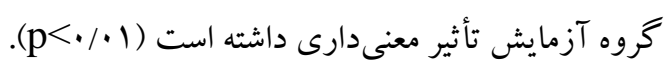

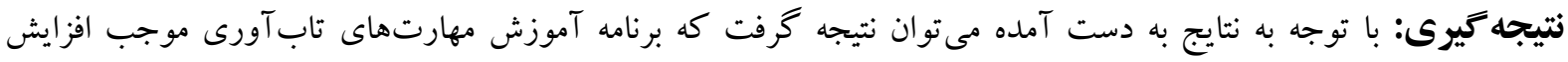

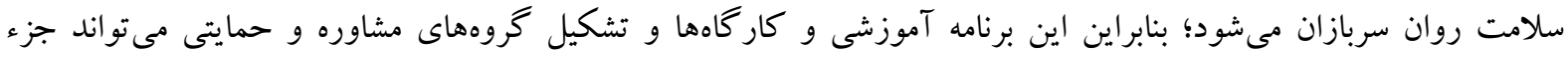

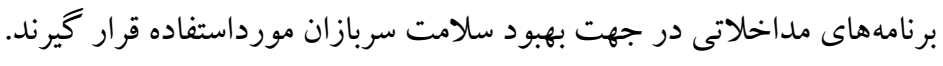
كليدوازهها: مهارتهاى تاب آورى، سلامت روان، سربازان 
جسمى، روانى و بهزيستى اجتماعى است (كودين'؛

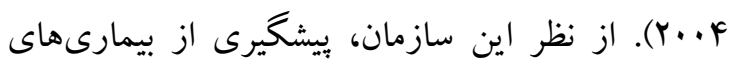

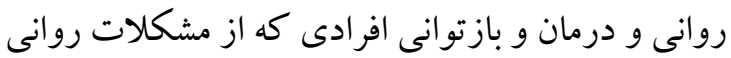
رنج مىبرند، نيز شامل بهداشت روانى است (خدرى و دباغى،سوس|). اهميت برداختن به بهزيستى و سلامت

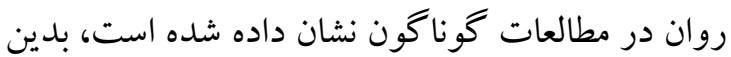
كونه كه افراد راضى و خشنود، هيجانات مثبت بيشترى را تجربه مى كنند و از رويدادهاى بيرامون خود

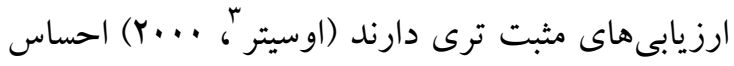
و مهار كنترل بالاترى دارند و ميزان بيشرفت تحصيلى و رضايت از زندگى بيشترى را تجربه مى كنند و نيز نظام ايمنى سالمتر و خلاقيت بالاترى دارند (محمدى يور و

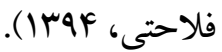
يكى از سازههاى روانشناسى مثبت كه احساس بهزيستى را در افراد تحت تأثير قرار مىدهد و سلامت متان روان را ارتقا مىدهد، تابآورى است (بهزاد يور و همكاران، سوسا). تابآورى به اين مسئله مىبردازد كه فرد عليرغم قرار گرفتن در معرض فشارهاى شديد و عوامل خطر مىتواند عملكرد اجتماعى خود را

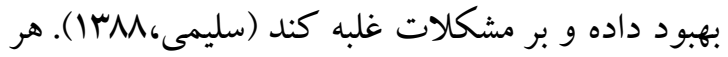
جند انديشه تاب آورى در مواجهه با شرايط ناگوار از سال ها قبل در افسانهها، اسطورهها و هنر و ادبيات وجود داشته است اما در اواخر قرن نوزده و اوايل قرن بيستم كه روانشناسى تحولى تكوين يافت، تمايل

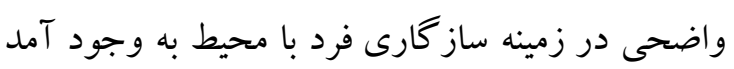
(قمى، اجس|). هال و همكارانش بيان مىدارند نياز به اين مسئله احساس مىشود كه افراد مهارتهايى را بياموزند كه هنكام مواجهه با مشكلات و موقعيتهاى

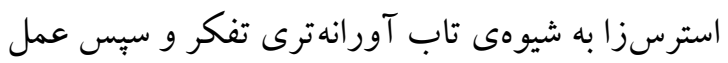
كنند. از اينرو، مداخلههايى كه هدفشان تحت تأثير

\footnotetext{
2. Goodwin
}

3. Ositer

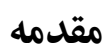
كليد ترقى، يويايى و اعتلاى هر جامعهاى در داشتن عناصر و اعضايى سالم و كار آمد در آن جامعه است، افرادى كه علاوه بر وضعيت جسمانى مناسب از لحاظ روانشناختى نيز در حد متعادل و مطلوبى باشند (خدرى و دباغى، سهبr). امروزه مشكلات و ناهنجارىهاى روانى در سربازان به دليل ماهيت فعاليت آنان در حال رشد است و سالانه هزينهاى بسيارى را به بخش سلامت تحميل مى كند (نورى و همكاران، . •وسا).

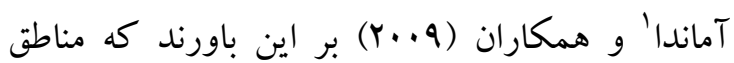
نظامى، تأثيرات روانشناختى مختلفى بر سربازان دارد. اين افراد ممكن است در معرض استرسهايى از قبيل

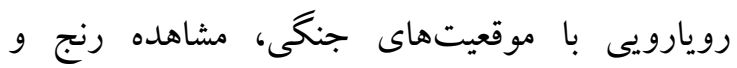
محروميت انسان، زندكى و شرايط كارى سخت، مونى جدايى از خانه و خانو اده و تعارض با همتايان نظامى يا مافوقها قرار كيرند (على محمدى و همكاران، •وس (1). ورود به سربازى و منطقهاى نآشنا وضعيت روانشناختى فرد را با جالش روبرو مى كند و سلامت روانى فرد را تحت تأثير قرار مىدهد. عدم توانايى در مقابله با اين فشارها و جالشها مى توتواند به شكل مشكلات هيجانى، افسردگى و ساير ناراحتىهاى روانى بروز كند. نقش بهلداشت روان در حوزههاى مختلف

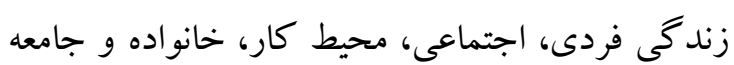
انكارنايذير است. بهلداشت روانى عبارت است از مجموعه عواملى كه در بيشخيرى از ايجاد و يا بيشرفت روند وخامت اختلالات شناختى، احساسى و رفتارى در لهر انسان نقش مؤثر دارند (وفايى و خسروى، (1)M). سازمان بهداشت جهانى، سلامت روانى را گستره وسيعى از فعاليتهاى مستقيم و غيرمستقيم مىداند كه به احساس بهزيستى روانى منجر مىشود. عناصر بهزيستى روانى از نظر اين سازمان شامل كمال وضعيت

. Amanda 
از بروز نابسامانى در يگگان ها بيشخيرى خواهد كرد، هدف اصلى از انجام يثوهش حاضر، بررسى اثربخشى مهارتهاى تابآورى در ارتقاى سلامت روان سربازان

طرح يثزوهش حاضر نيمه تجربى و از نوع ييش آزمون -

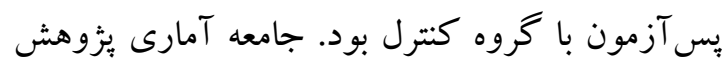
شامل كليه سربازان وظيفه ستاد انتظامى استان كرمانشاه بود. براى انتخاب نمونه از نمونه كيرى در دسترس استفاده شد پِ از اخذ رضايتنامه از افراد جهت

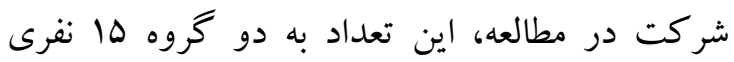
شامل گرووه آزمايش و كنترل تقسيم شدند. يس از انتخاب شر كت كنند كان و گمارش تصادفى آنان در دو

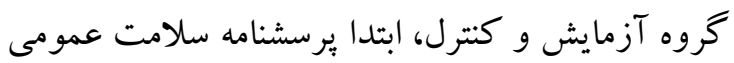

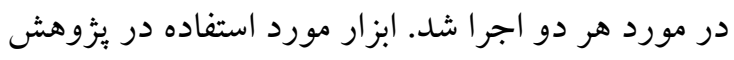

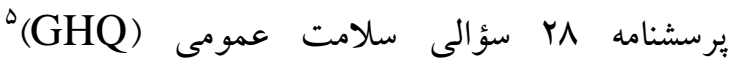
كلدبرگك بود. اين مقياس يكك ابزار خود گزارشدهى براى ارزيابى سلامت روان افراد است. اين برسشنامه از F زيرمقياس تشكيلشده است كه شامل؛ شكايات جسمانى، اضطراب، نارسا كنشورى اجتماعى و

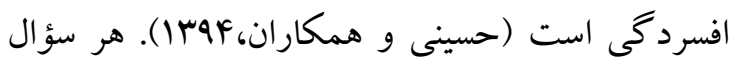
اين برسشنامه در يكك طيف ليكرت جهارتايى نمرهكذارى مى شود. بِيايى كلى اين برسشنامه $90 \%$ كزارش شده است. همجنين بِايايى درونى مؤلفههاى

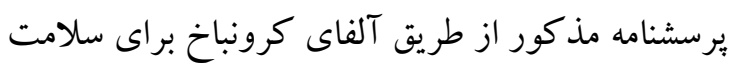

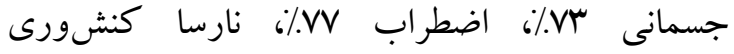

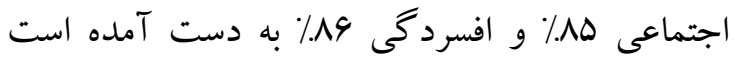
(حاجلو و همكاران، (1) أوسى).

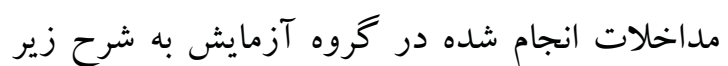
بود: منظور از آموزش تاب آورى به كارگيرى

. General Health Questionnaire
قراردادن فر آيندهاى فكرى است، مى تواند گام مهمى در ايجاد مهارتها و توانايىهاى مربوط به تابَآورى

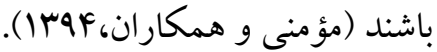

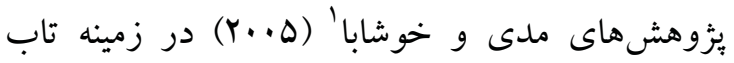
آورى نشان داد تابآورى مىتواند در زمينههاى مدى روانى، هيجانى و اجتماعى نقش اساسى در روابط بين فردى افراد داشته باشد .اين محققان بر اين باور

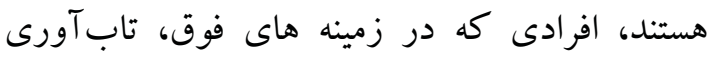

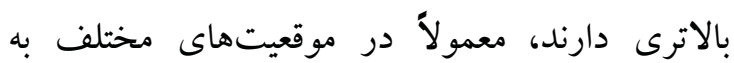
خصوص در موقعيتهاى استرس آفرين زندگى رفتارهاى بهنجار و ثبات يافتهترى از خود نشان

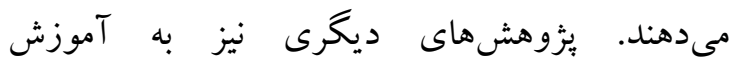
مهارتهاى تابآورى در موقعيت هاى گوناكون يرداخته اند. در همين راستا مى توان به بُزوهش برينس

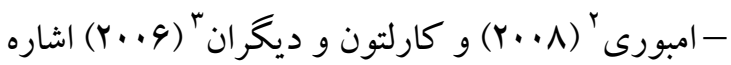
كرد كه دريافتند نوجوانان برخوردار از تاب آورى بالا از سلامت روانى بالاترى برخوردار هستند. يُوهش

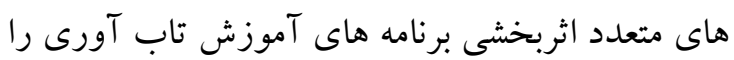

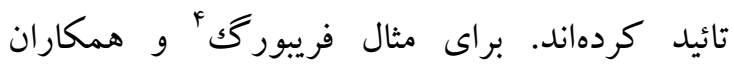
معتقدند مداخلههايى كه با هدف يرورش (Y..V) تابآورى و افزايش ساز كارى مثبت با شرايط ناگوار

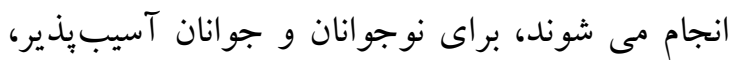

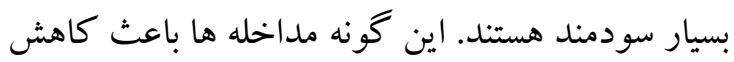
احتمال عود يا وخامت مشكلات روانشناختى آنها

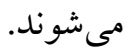
مطالعات بِيشين به طور آشكار به بررسى تأثير آموزش تاب آورى بر سلامت روان سربازان نِرداختهاند و با در نظر گرفتن آنكه توجه به اين گروه از افراد جامعله،

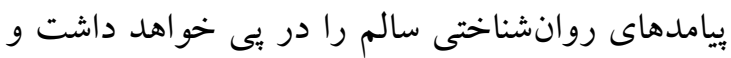

\footnotetext{
. Maddi \& Khoshaba

2 . Prince - Embury

3. Carlton \& et el

4 . Friburg \& et el
} 

مولفه هاى اجتماعى شامل توانايى شكل دادن و

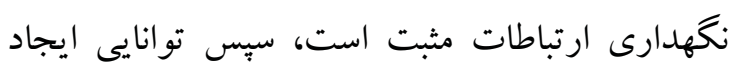
ارتباط كلامى و غير كلامى آموزش داده مى شود، سبِ درباره همكارى گروهى و ايجاد حس خود اثربخشى بحث مى شود و در نهايت در اين مرحله به ايجاد حس شوخ طبعى اقدام مى شود. مولفه شناختى شامل فراشناخت و ايجاد اهداف آتى است كه حل مسئله و قدرت مولفه تصميم كيرى و حفظ باورهاى مذهبى و معنوى و توجه به اهداف آينده را شامل مى

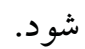

فنون هاى هيجانى، اجتماعى و شناختى است كه طى

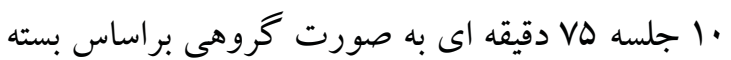

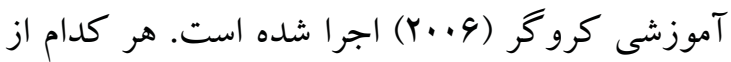

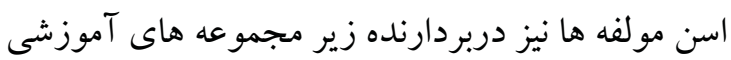
مختلفى هستند. مولفه هيجانى شامل شناخت و مديريت

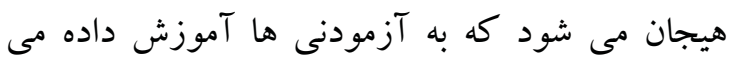
شود تا بتوانند موقعيت هاى مناسب براى ابراز هيجانات

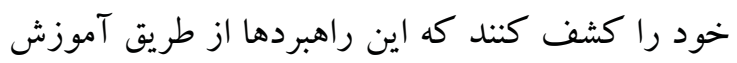
مهارت هاى آرامش سازى عضلانى تدريجى و تمرين هاى تصويرسازى ذهنى است، سبس راه هاى ارتقاء و افزايش همدلى بحث مى شود.

جدول ا. محتواى جلسات آموزشى

\begin{tabular}{|c|c|}
\hline 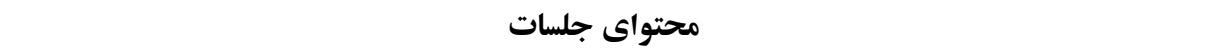 & جلسات \\
\hline معرفى برنامه آموزشى، آشنايى با مغاهيم، ساختار، مراحل، روش اجراى برنامه و تكاليف & جلسه اول \\
\hline شناسايى و كنترل هيجان ها & 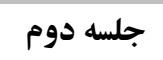 \\
\hline آموزش روش هاى برورش و ارتقاء سطح همدلى و رفتار نوع دوستى و سهيم شدن & جلسه سوم \\
\hline آرامش سازى عضلانى تدريجى وازٔه خود دانى و خود تاب آورى و تفاوت آنها از طريق تصويرسازى ذهنى و آموزش مهارت هاى & جلسه جهارم \\
\hline توانايى شكل دهى روابط مثبت و ابقاء آن و توانايى برقرارى رابطة اثربخش كلامى و غير كلامى & جلسه ينجم \\
\hline آموزش حس شوخ طبعى - مشار كت گروهى اثربخش & جلسه ششم \\
\hline آموزش حس خودشناسانى، خود ادراكى مثبت و خود اثربخشى & جلسه هفتم \\
\hline آموزش فراشناخت، حل مسئل، بررسى خرخة افكار منفى و آموزش تلاش براى رشد نخرش مثبت & جلسه هشتم \\
\hline بررسى حفظ باورها و انتظارات مذهبى يا معنوى و اهداف آينده & جلسه نهم \\
\hline مرور توانايىهاى فراكرفته شده در طى جلسات و يكيار خهسازى تاب آورى هيجانى، اجتماعى و شناختى & جلسه دهم \\
\hline
\end{tabular}

يافته ها

جدول شماره (Y) ميانگين و انحر اف معيار سربازان را در هريك از مؤلفههاى سلامت روان نشان مىدهد.

جدول r. مقايسه ميانكين نمرات مؤلفههاى سلامت عمومى سربازان در كروههاى آزمايش و كنترل در مراحل ييش آزمون و يس آزمون

\begin{tabular}{|c|c|c|c|}
\hline سطح معنىدارى & "ِس آزمون & ي ييش آزمون & مؤلفه هاى سلامت روان \\
\hline.$/ . \cdot 1$ & & & شكايات جسمانى \\
\hline & $\Lambda / r \cdot \pm r / r r$ & $\mid r / v \cdot \pm r / \cdot 1$ & آزمايش \\
\hline & $\mid r / q \cdot \pm r / \Delta F$ & $|r / r \cdot \pm r / N|$ & كنترل \\
\hline$\cdot / \cdot \Delta$ & & & اضطراب \\
\hline
\end{tabular}




\begin{tabular}{|c|c|c|c|}
\hline & $9 / 9 \cdot \pm r / f r$ & $10 / 9 \cdot \pm F / F \Delta$ & آزمايش \\
\hline & $\mathrm{IV} / \mathrm{Ir} \pm F / 19$ & $19 / 9 \cdot \pm r / r$ & كنترل \\
\hline \multirow[t]{3}{*}{$\cdot / \cdot r$} & & & نارساكنش ورى اجتماعى \\
\hline & $1 \cdot / \cdot \Lambda \pm r / \cdot r$ & $I V / F \cdot \pm r / I r$ & آزماش \\
\hline & $|r /| \cdot \pm r / r \Lambda$ & $\mid F / r \cdot \pm r / \Delta \varphi$ & كنترل \\
\hline \multirow[t]{3}{*}{$\% \mu$} & & & افسردىى \\
\hline & $9 / \wedge \cdot \pm r / r r$ & $19 / 1 r \pm r / Y 9$ & آزمايش \\
\hline & $|F / F \Delta \pm F /| r$ & $M / M T \pm F / M F$ & كنترل \\
\hline
\end{tabular}

طبق يافته هاى جدول شماره (Y) بين مؤلفه هاى سلامت مهارتهاى تاب آورى باعث ايجاد تفاوت معنىدار در

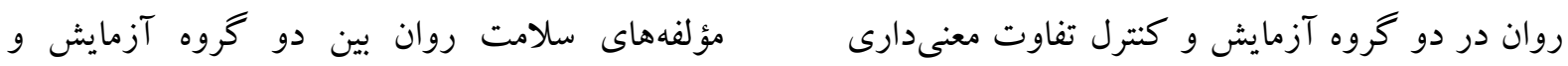

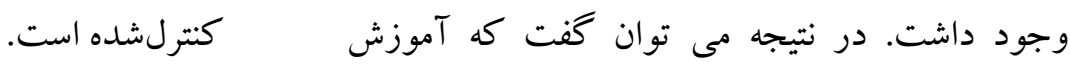

\begin{tabular}{|c|c|c|c|c|c|c|}
\hline مجذور & sig & $\mathbf{F}$ & ميانكين مجذورات & آزادى & مجموع مجذورات & منبع واريانس \\
\hline$\cdot|Y|$ & $.1 . Y 9$ & $F F N / Y$ & $r Y / \Delta \Lambda$ & if & $9 \pi \Delta / \cdot \Delta \Delta$ & ييش آزمون \\
\hline \multirow[t]{3}{*}{.1999} & $\cdot / \cdot 1$ & $\mu \varphi / . r$ & $9 \cdot r / I V$ & 1 & $9 \cdot r / \cdot \Lambda \cdot$ & كروه \\
\hline & & & $I T / V Y$ & If & $r 9.19 \mathrm{~V}$ & خطا \\
\hline & & & & $r$. & $r r / .+r$ & كل \\
\hline
\end{tabular}

نتايج حاصل از اجراى تحليل كواريانس در جدول روان سربازان بوده، نتايج بهدستآمده نشان داد كه

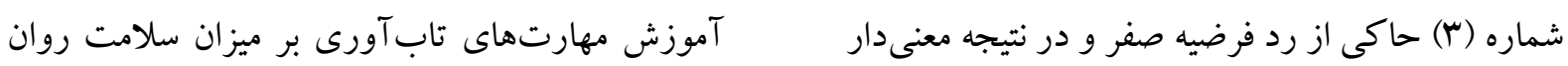

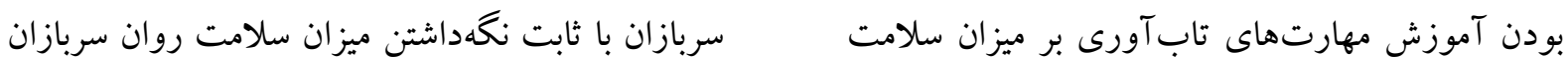

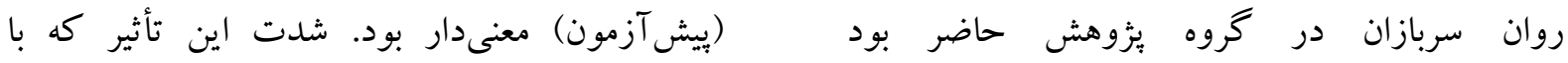

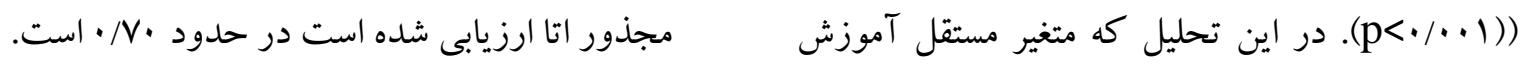

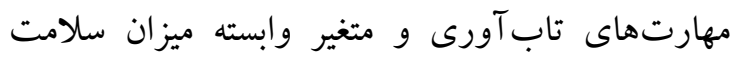

\begin{tabular}{|c|c|c|c|c|c|}
\hline اندازه اثر & سطح معنادارى & درجه آزادى r & درجه آزادى 1 & $\mathbf{F}$ & متغير \\
\hline$. / F+\wedge$ &.$/ 190$ & 19 & 1 & .1994 & سلامت روان \\
\hline
\end{tabular}


اين نكته اشاره كرد كه در جلسههاى آموزش تابآورى، روشهاى آموزش مهارتهاى مقابله، آموزش معنا خو اهى و جستجوى معنا، بازسازى شناختى و ايجاد

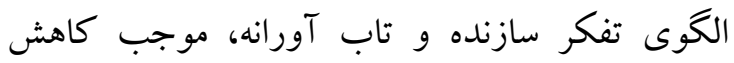

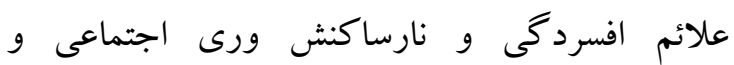
مهارتهاى تصويرسازى ذهنى و آرامش سازى عضلانى تدريجى موجب كاهش اضطراب و شكايات جسمانى شده است. از آنجا كه يادگيرى برخى

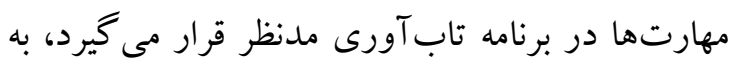
نظر مىرسد شر كت افراد در اين برنامه موجب مىشود، آنها همواره تلاش كنند مثبت بينديشند، به رويدادهاى ناخوشايند لبخند بزنند، روحيه شوخ طبعى خود را حتى در شرايط ناكوار نيز حفظ كنند، در شرايط دشوار و سختى از ديخران كمكك بخيرند و سعى كنند با نظارت و مديريت افكار، احساسات و اعمال خود را كنترل كنיد. يكى ديخر از دلايل اثربخشى آموزش تابآورى بر

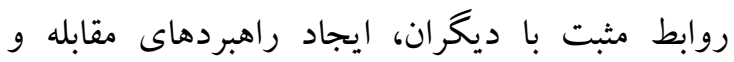
سازو كارهاى دفاعى بهتر در افراد و آموزش دلكرم سازى خود و ديكران است. همجِنين با توجه به اينكه اجتناب از سوءظن و قضاوت زودهنگام در مورد ديخران، خوشاخلاقى، كلام خوشايند و رهاسازى ارع ذهن از موضوعات بىاهميت، بخشى از عناصر

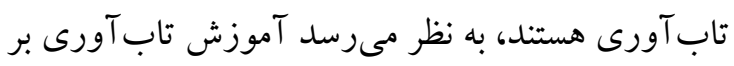

$$
\text { روابط مثبت با ديخران اثربخش باشد. }
$$

در مجموع مىتوان نتيجه گرفت گنجاندن مداخلههاى آموزش تابآورى در برنامه مراكز آموزش نظامى و

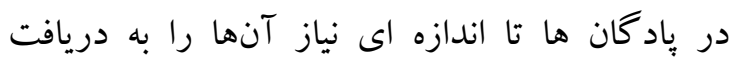
خدمات روانشناختى تأمين مى كند و از اين طريق در باد اله افزايش سلامت روانشناختى و ويشخيرى از بروز مشكلات آنها كام مؤثرى برمىدارد. با توجه به نتايج

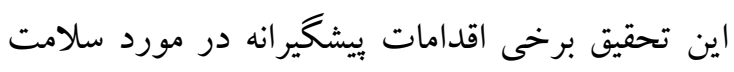

جدول شماره \& توان آزمون را مورد بررسى قرار مىدهد. اين ميزان (سطح معنىدارى) هرجه بهطرف 1 نزديكتر باشد نشان از توان بالاى آزمون است. بر اساس جدول توان آزمون در حد متوسط قرار دارد.

\section{بحث و نتيجه تيرى} يزوهش حاضر با هدف بررسى اثربخشى آموزش مهارتهاى تابآورى بر سلامت روان سربازان انجام شد. يافتهاى بهدست آمده از نتايج ميانگين نمرههاى

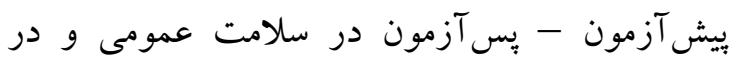
خرده مقياسهاى علائم جسمانى، علائم اضطرابى و نقص در عملكرد اجتماعى نشان داد كه بين گروه آزمايش و كروه كنترل تفاوت معنىدار وجود دارد. نتايج حاصل از اين بررسى با نتايج بثوهشهاى انجام

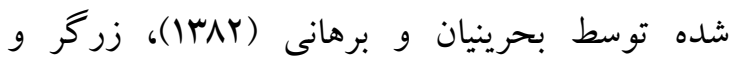
همكاران (IMNV) شجاعى و همكاران (rarا) همسو است. يافتهاى مطالعه كاتالانو' و همكاران (Y...... نشان داد اين كونه آموزشها با افزايش خودانگيختكى، لياقت اجتماعى و همدلى همراه بوده و بهبود سلامت روانشناختى را به دنبال دارد. يرينس امبورى (Y..人) اظهار داشتهاند جوانانى كه از تابآورى بالاترى برخوردارند، سلامت روانى آنها نيز بالاتر است. در ابله

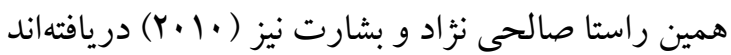
بين تاب آورى و بهزيستى روانى، رابطه مثبت معنادار و بين تابآورى و درماندگى روانى، رابطه منفى وجود

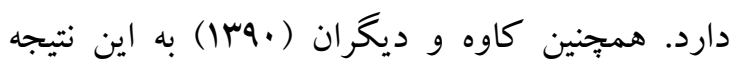
دست يافتهاند كه برنامههاى مداخلهاى تاب آورى باعث افزايش بهزيستى ذهنى مىشود. در تبيين اثربخشى

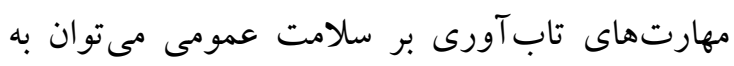


Carlton BS, Goebert DA, Miyamoto RH, Andrade NN, Hishinuma ES, Makini GK, et al. (2006). Adolescents resilience family adversity and well-being among Hawaiian and non-Hawaiian adolescents. Int J Soc Psychiatry; 52:291-300.

Catalano RF, Berglund ML, Ryan JAM, Lonczak HS, Hawkins JD. (2002). Positive youth development in the United States: Research findings on evaluations of positive youth development programs. Prev Treat. 5(1):515.

Faramarzi, S; Homaee, R; Ezadi, R. (2011). The effectiveness of group cognitive-behavioral life skills and mental health of women with handicapped spouses. Joumal of Social Welfare. 11, (40). 217-235. (Persian)

Friborg, O., Barlaug, D., Martinussen, M., Rosenvinge, J. H., \& Hjemdal, O. (2005). Resilience in relation to personality and intelligence. Intemational Joumal of Methods in Psychiatry Research, 14, $29-42$.

Gutjahr, A. R. (2007). Child resilience program: An intervention for children of chronically mentally ill parents. PhD Thesis, School of Psychology, Spalding University, Louisville, Kentucky.

Hajloo N, Sharifi AR, Vahedi S. (2012). Correlatives of individual identity in high school female students at Ardabil city. J Sch Psychol. 1(2):21-38. (Persian)

Hiemdal, O., Aune, T., Reinfjell, T., Stiles, T. C. \& Friborg, O. (2007). Resilience as predictor of depressive symptoms: A comelation study with young adolescents. Clinical Child Psychology and Psychiatry, 12, 91-104.

Hoseini Gomi, T, Bajestani Salimi, H. (2013). Effects of matemal stress resilience training of children with cancer in Imam Khomeini Hospital, Tehran. Journal of Health Psychology.1.(4). 97. 109(Persian)

Khedri, B; Dabbakhi, P. (2014). Effective problem solving skills on the mental health of soldiers. Ebnesina - IRIAF Health Administration.. 16(1-2,). IV-Yo

Maddi,S.R \& Khoshaba,DM. (2005). Resilience at work. AMA com, American management Association, 1601, Broadway, N.Y10019.

Mohammadipoor, M, Falahati, M. (2016). Effectiveness of Life Skills Training on

$$
\begin{aligned}
& \text { روان سربازان به شرح زير يِينهاد مىشود: () مشاوره، } \\
& \text { راهنمايى و حمايت فرد در محيط هاى نظامى؛ r) } \\
& \text { همبستگى اجتماعى در محيط هاى نظامى تقويت شود؛ } \\
& \text { r) تعميق باورها و نكرش هاى دينى با به كار گيرى شيوه }
\end{aligned}
$$

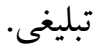

$$
\begin{aligned}
& \text { با توجه به اينكه در بثزوهش حاضر تأثير آموزش } \\
& \text { مهارتهاى تابآورى بر ميزان سلامت روان مورد } \\
& \text { توجه قرار گرفت، بيشنهاد مى شود در يثزوهش هاى آتى برى } \\
& \text { بيشتر بر آموزش تابآورى بر شادكامى، كيفيت } \\
& \text { زندگىى، استرس شغلى، حس غربت و ديخر مؤلفههاى }
\end{aligned}
$$

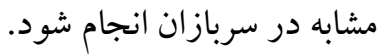

$$
\begin{aligned}
& \text { تشكر و قدردانى } \\
& \text { از فرماندهى قرار گاه ستاد انظامى استان كرمانشاه و } \\
& \text { دفتردار قرار كاه آقاى اميرى كه نهايت همكارى را در } \\
& \text { انجام اين يُزوهش داشتهاند، تشكر و قدردانى مى شودد. }
\end{aligned}
$$

\section{References}

Amanda, G. Ferrier-Auerbach, Christopher, R. Erbes., \& Scott R. (2009). "Predictors of emotional distress reported by soldiers in the combat zone" Joumal Of Psychiatric Research, doi:10. 1016.

Bahreinian A, Borhani H.(2002) Mental health in group of war veterans and their spouses in Qom. Res Med.;27(4):305-12. (Persian)

Bajestani Salimi, H. (2008). Compare the effectiveness of cognitive restructuring counseling based Brtmsyl Adler and mental health, resilience and hope the students of psychology Tabatabai. Completed a doctorate in counseling psychology. Psychology Faculty of Allameh Tabatabai. (Persian)

Behzadpoor, S; Motahhari, Z; Vakili, M; Sohrabi, F. (2013). The impact of increased resilience training on psychological well-being infertile women. Scientific Journal of Ilam University of Medical Sciences. 23(5). 131.142(Persian) 
Mental Health ofSpouses of Veterans with Affective Disorders. Quarterly of Iranian Joumal of War \& Public Health;8(1):25-32

Momeni KH, Jalili Z, Mohseni R, Karami J, Saeedi M, Ahmadi SM. (2015). Efficacy of teaching resiliency on symptoms reduction on anxiety of adolescence with heart disease. J Clin Res Paramed Sci; 4(2):112-119. (Persian)

Neenan, M. (2009). Developing resilience: A cognitive - behavioural approach. Developmental psychopathology. 1(7): 261-294).

Nouri R, Fathi AA, Salimi SH, Azad ME, Esmaeli AA. (2011). An investigation of personality traits, physical and mental health in relation to committed suicide in a group of military soldiers. Joumal of military psychology; 2(5):47-55. (Persian)

Ositer GR, Markindes KS, Black SA, Goodwin JS. (2000). Emotional wellbeing predicts ubsequent functional independence and survival. J Am Great Soc. 48(5):473-8.

Prince-Embury, S. (2008). Translating resiliency theory for assessment and application in schools. Canadian Journal of School Psychology, 23, 4-10.

Vafaee, T; Khosravi, s. (2009). Comparing the mental health of devotees spouses and normal persons spouses. Joumal of War \& Public Health. 1(4). 9-13.

Zargar,F; Moradi, A; Imani, S. (2007). To compare runaway girls and normal personality traits and women in Isfahan. Joumal of Applied Psychology. 3,(10). 47-58. 